\title{
Edessa rufomarginata (Hemiptera: Pentatomidae) feeding on Solanum lycocarpum (Solanaceae) in rupestrian fields of the Brazilian Cerrado biome
}

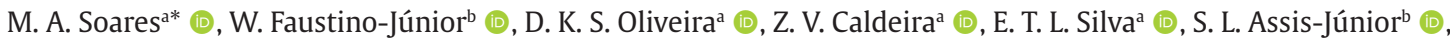 \\ J. C. Zanuncio ${ }^{c}$ (i) and A. J. V. Zanuncio ${ }^{\mathrm{d}}$ (D) \\ a Universidade Federal dos Vales do Jequitinhonha e Mucuri - UFVJM, Programa de Pós-graduação em Produção Vegetal, Diamantina, MG, Brasil \\ ${ }^{\mathrm{b}}$ Universidade Federal dos Vales do Jequitinhonha e Mucuri - UFVJM, Programa de Pós-graduação em Ciência Florestal, Diamantina, MG, Brasil \\ ' Universidade Federal de Viçosa - UFV, Departamento de Entomologia/BIOAGRO, Viçosa, MG, Brasil \\ 'Universidade Federal de Viçosa - UFV, Departamento de Engenharia Florestal, Viçosa, MG, Brasil
}

The stink bugs Edessinae subfamily (Hemiptera: Heteroptera: Pentatomidae) has six genera described in the neotropical region, including Edessa Fabricius 1803, Olbia Stál 1862, Pantochlora Stál 1870 and Peromatus Amyot \& Serville 1843, with 259, 1, 5 and 7 species, respectively (Fernandes and Van Doesburg, 2000).

Solanum lycocarpum Saint Hilaire (Solanaceae) is an abundant native shrub in the Brazilian Cerrado. Humans do not commonly consume its fruits, but they are rich in starch. This plant can reach up to $3.5 \mathrm{~m}$ in height, has rough leaves with thorns, a high tolerance to water and climate stress, a high survival capability, and produces fruit throughout the year. A single $S$. lycocarpum plant can produce 40 to 100 fruits in the year with potential for biofuels production (Morais et al., 2019). Brazilian folk medicine also uses these fruits to treat diabetes, control obesity and to reduce cholesterol levels (Farina et al., 2010).

The objective of this study was to describe, for the first time, the occurrence of an Edessa species feeding on Solanum lycocarpum plants in rupestrian fields of the Brazilian Cerrado biome.

Adults and immatures of the Edessa were detected between May and June 2018, October to December 2019 and from January to February 2020, feeding on S. lycocarpum plants in rupestrian fields near the "Vale dos Diamantes" neighborhood of Diamantina municipality, Minas Gerais state, Brazil (18.2494440 ${ }^{\circ} \mathrm{S}$, $43.3600278^{\circ} \mathrm{W} ; 1,280$ masl). The local climate is Cwb - dry winter subtropical highland, according to the Köppen classification (Köppen, 1936), with dry winters and rainy summers. This site has 28.5 ha with rupestrian fields and mountain grassland preserved in Diamantina (Soares et al., 2019). The type of vegetation is predominantly composed of a continuous herbaceous stratum and small, sclerophyllous evergreen shrubs. Local soils are predominantly sandy, with low moisture retention, interspersed with large rock outcrops of quartzite. Insect detections were performed on S. lycocarpum plants in the area bordering the buildings (in a $300 \mathrm{~m}$ linear transect towards east to west), observing 30 plants.

Adults of Edessa were collected and placed in $70 \%$ alcohol in glass vials. The insects collected were assembled through entomological pins and kept in entomological boxes in the collection of the Federal University of Jequitinhonha and Mucuri Valleys. Individuals were sent to Dr. José Antônio Marin Fernandes of the Biology Department, Federal University of Pará, in Belém, Pará state, Brazil, who identified them as Edessa rufomarginata De Geer, 1773 (Hemiptera: Pentatomidae).

Adults of E. rufomarginata were observed mating and sucking on S. lycocarpum leaves, stems and fruits (Figure 1). Immatures were also found feeding on S. lycocarpum plants during the evaluation period.

Edessa rufomarginata is a neotropical Pentatomidae, herbivore, widely distributed from Mexico to Argentina. This stink bug has been widely studied in Argentina, where it feeds on both wild and cultivated plants, mainly of the Solanaceae family such as Nicotiana tabacum Linnaeus, Solanum lycopersicum L., Solanum melongena L. and Solanum tuberosum L. (Rebagliati et al., 2003). In Brazil, E. rufomarginata has been reported in the Cerrado biome (savanna) on Caryocar brasiliense Cambessèdes (Caryocaraceae) as an important pest of this native plant (Leite et al., 2016).

Edessa rufomarginata could establish on S. lycocarpum causing damage to this plant. Immature stages of E. rufomarginata were observed on S. lycocarpum, which suggests that this insect can complete their biological cycle and is in the process of adapting to this new host. This could also facilitate its dispersal to $C$. brasiliense, a plant with high commercial importance which is abundant in the Brazilian Cerrado region, as well as to other plants of

*e-mail: marcusasoares@yahoo.com.br

Received: March 30, 2020 - Accepted: August 18, 2020 


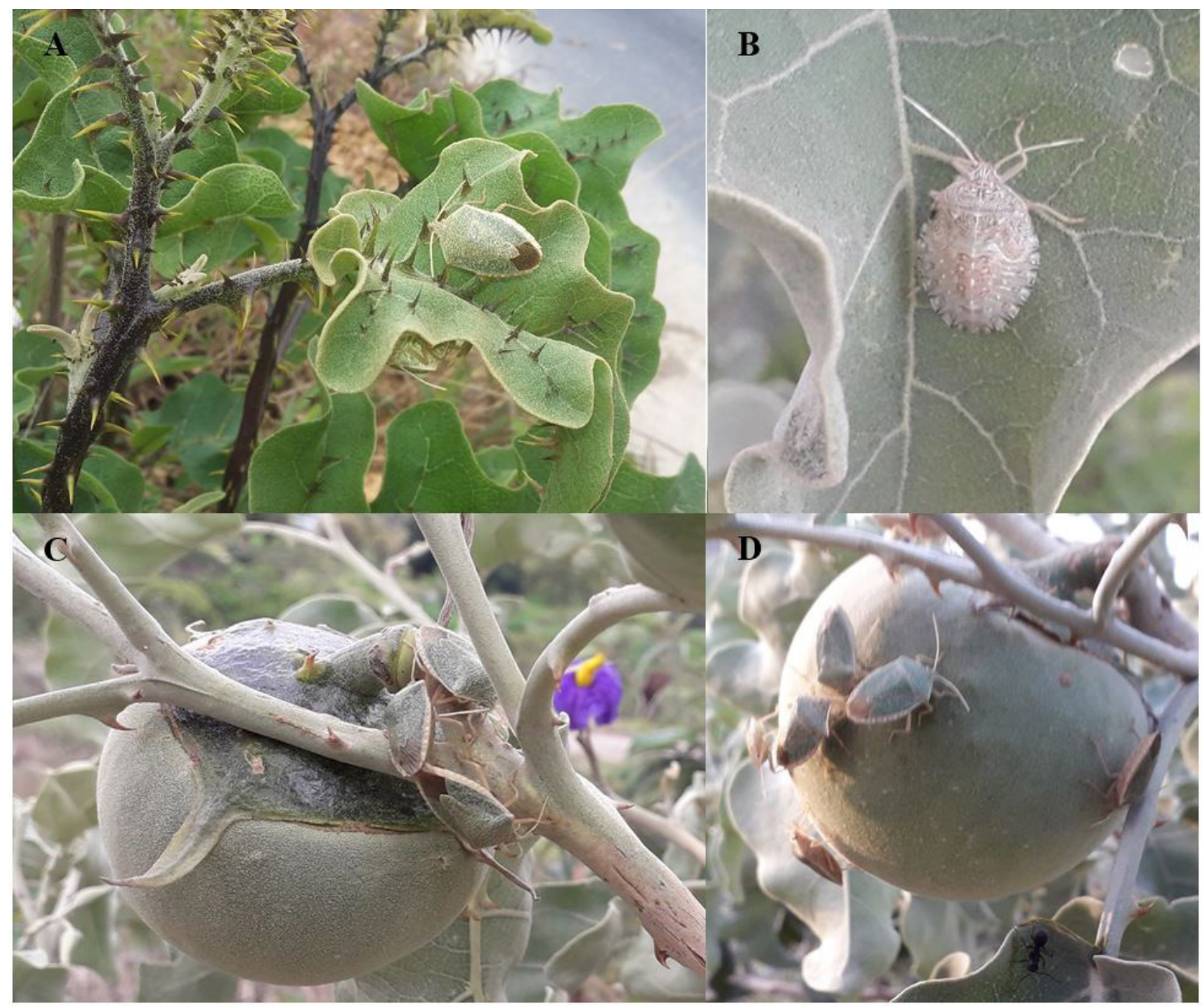

Figure 1. Edessa rufomarginata (Hemiptera: Pentatomidae) adults on leaf (A), immature on leaf (B), adults on stems (C), and in fruit (D) of Solanum lycocarpum (Solanaceae) plants in Diamantina, Minas Gerais State, Brazil.

the Solanaceae family. However, systematic evaluations are necessary to confirm these hypotheses.

\section{References}

FARINA, F., PIASSI, F.G., MOYSÉS, M.R., BAZZOLLI, D.M. and BISSOLI, N.S., 2010. Glycemic and urinary volume responses in diabetic mellitus rats treated with Solanum lycocarpum. Applied Physiology, Nutrition, and Metabolism, vol. 35, no. 1, pp. 40-44. http://dx.doi.org/10.1139/H09-131. PMid:20130665.

FERNANDES, J.A.M. and VAN DOESBURG, P.H., 2000 [viewed 30 March 2020]. The E. dolichocera-group of Edessa, Fabricius, 1803 (Heteroptera: Pentatomidae: Edessinae). Zoölogische Mededeelingen [online], vol. 73, pp. 305-315. Available from: https://www.repository.naturalis.nl/document/44299four

KÖPPEN, W., 1936. Das geographische system der klimate. In: W. KÖPPEN and R. GEIGER, eds. Handbuch der Klimatologie. Berlin: Gebrüder Bornträger, pp 1-44.

LEITE, G.L.D., LOPES, P.S.N.,ZANUNCIO, J.C., MARTINS, C.D.P.S., MOREIRA, T.M.B. and COSTA, R.I.F.D., 2016. Effects of environmental and architectural diversity of Caryocar brasiliense (Malpighiales: Caryocaraceae) on Edessa ruformaginata (Hemiptera: Pentatomidae) and its biology. Acta Scientiarum. Agronomy, vol. 38, no. 1, pp. 19-27. http://dx.doi.org/10.4025/actasciagron.v38i1.26244.

MORAIS, R.R., PASCOAL, A.M., PEREIRA-JÚNIOR, M.A., BATISTA, K.A., RODRIGUEZ, A.G. and FERNANDES, K.F., 2019. Bioethanol production from Solanum lycocarpum starch: a sustainable non-food energy source for biofuels. Renewable Energy, vol. 140, pp. 361-366. http://dx.doi.org/10.1016/j.renene.2019.02.056.

REBAGLIATI, P.J., PAPESCHI, A.G. and MOLA, L.M., 2003. Meiosis and fluorescent banding in Edessa meditabunda and E. rufomarginata (Heteroptera: Pentatomidae: Edessinae). European Journal of Entomology, vol. 100, no. 1, pp. 11-18. http://dx.doi.org/10.14411/ eje.2003.002.

SOARES, M.A., SÁNCHEZ, L.P., ISAAC JÚNIOR, J.B., PEREIRA, E.S., PIRES, E.M., LEITE, G.L.D. and ZANUNCIO, J.C., 2019. Solanum lycocarpum Saint Hilaire (Solanaceae) is host plant of Leucanella memusae (Walker) (Lepidoptera: Saturniidae: Hemileucinae) in Brazilian mountain grasslands. The Florida Entomologist, vol. 102, no. 3, pp. 624-626. http://dx.doi. org/10.1653/024.102.0341. 